\title{
Investigating the Persuasive Pronominal Choices in Barack Obama's International Speeches to the Muslim and Non-Muslim Worlds
}

Mervat Ahmed Gaber Attia

Damanhur University 


\title{
Investigating the Persuasive Pronominal Choices in Barack Obama's International Speeches to the Muslim and Non-Muslim Worlds \\ Mervat Ahmed Gaber Attia
}

Damanhur University

\begin{abstract}
The current research tackles five international speeches of Barack Obama to the Muslim and Non- Muslim worlds during his rule from 2009 to 2015. It focuses on the analysis and investigation of first-person pronouns "I" and "we" which are used skillfully as tools for persuasion. It adopts Chilton and Schaffner (1997) and Obeng and Hartford (2002) for studying pronouns. The pronoun "I" is used to express feelings and emotions, narration, declarations, knowledge, personal views and thoughts. The pronoun "we" is used to express solidarity, allegiance, proximity and friendliness. The results of the research prove that Barack Obama accurately uses these personal pronouns to create an atmosphere of solidarity and rapport which leads to persuasion of the audiences.
\end{abstract}

Key terms: personal pronouns, persuasion, rapport, Barack Obama, Muslim world, Non-Muslim world. 


\section{Introduction:}

Pronouns are important linguistic features of political discourse. They worth investigation as they are used skillfully by Barack Obama in his international speeches to the Muslim and Non - Muslim worlds from 2009 to 2015. In light of Chilton and Schaffner (1997), the pronoun "I" is used in all the speeches to represent Barack Obama as an authoritative speaker who makes decisions, issues orders, commands, advices, informs, narrates, declares and describes actions. According to Obeng and Hartford (2002), the pronoun "we" is used to express community and allegiance and depicts the speaker as a spokesperson for his people.

\section{Questions of the Research:}

The present research tries to answer the following questions:

1- What are the persuasive first person pronouns employed by President Obama in the speeches under study ?

2- How are these persuasive first person pronouns used to influence the audiences?

\section{Literature Review:}

Political discourse occupies a privileged position in research nowadays. Scholars have contributed to the field of political discourse analysis with numerous studies. These contributions include: Chilton \& Schaffner (1997; 2002), Obeng \& Hartford (2002) Van Dijk (2002; 2004), Joseph (2006), Okulaska \& Cap (2010),and Fairclough \&Fairclough (2012). Research in political discourse analysis has focused on the investigation of the genre of political speeches of world leaders. For example, Allen (2006) focuses on the analysis of Australian political discourse, El- Hussari (2010) presents a critical discourse analysis of George Bush's 
speech on Iraq war in 2007, Fraser (2010) studies hedging in the POLITICAL DISCOURSE OF George Bush, Al-Mizori (2011) focuses on the linguistic methods USA politicians used to justify the invasion of Iraq, Sharndama \& Mgbemena (2015) study Nigerian political discourse and Mazlum \& Afshin (2016) compare the language of President Barack Obama and President Hassan Rouhani.

Recent researches have focused on Barack Obama's international speeches. Of these researches is Gadalla's (2012) study which tackles Barack Obama's speech at Cairo University in 2009 in Egypt. It seeks to uncover the hidden ideologies underlying the speech employing Van Dijk's (1998 - 2006) model of critical discourse analysis. It investigates the discursive and ideological features of the speech. It focuses on the analysis of form (syntactic structures), meaning (semantics) and actions (communicative and speech acts).

Aschale (2013) analyzes four speeches of Barack Obama during the period from 2009 to 2013. Two speeches are delivered outside the USA: "Speech on "A New Beginning" by President Barack Obama, Cairo University 2009", and "Speech by President Barack Obama on his Israeli trip to the Israeli Young People, Jerusalem 2013". The other two speeches are delivered in the USA: "Speech by President Barack Obama on U.S. Policy in the Middle East and North Africa, Washington, DC 2011", and "Speech by President Barack Obama at American Israel Public Affairs Committee (AIPAC) Policy Conference, Washington, DC 2012".The aim of this study is to investigate Barack Obama's representation of America ; to investigate Barack Obama's ideologies and strategies towards these countries and audiences; as well as to 
investigate how Barack Obama influences and persuades his audiences but keeping the American power and hegemony at the same time. This study employs critical discourse analysis approaches based on analyzing linguistic and semiotic aspects combined with investigating the strategy of narration of certain concepts like religion, morality, ideology, identity and change as well as a word count analysis of critical themes. The results of the study revealed that Barack Obama is able to influence and persuade his audiences through his language and the aforementioned strategies and is able to keep the American hegemony when dealing with the others even with the allies.

Sajjad (2015) investigates Barack Obama's speeches to the Muslim World and the Middle East. This study investigates the underlying and implicit agendas, doctrines and ideology of Barack Obama's speeches towards the Muslim World and the Middle East. Moreover, it investigates the themes of change, democracy, hegemony, human rights, women's rights, and religion and morality. This study employs Fairclough's (2002) approach of critical discourse analysis as an analytical framework. The results reveal that Barack Obama is a skilful orator and intelligent politician. He is able to reach his different audiences through his language which is packed up with positiveness, optimism and change but at the same time keeping the interests of the USA and its allies. He always targets the young youth to follow his views.

It is hoped that the present research makes a positive contribution to the field of applied linguistics in general and to the field of political discourse analysis in particular. This research will inspire other researchers with new insights for approaching political discourse in the light of persuasive 
first person pronouns. It adds to the literature of analyzing political discourse as it compares Barack Obama's speeches to the Muslim and Non-Muslim worlds from 2009 to 2015.

\section{Theoretical Framework: Pronouns:}

The term "pronoun" first appeared in the English language in the sixteenth century. It originates in the Latin term "pro-nomen' and the Greek term "anto-numia" which means "standing for a noun" (Wales, 1996 , p. 1).

A pronoun is defined as a word which stands for a noun and its meaning and reference are only determined from the context of the utterance. There are different categories of pronouns like: personal pronouns, demonstrative pronouns, reflexive pronouns, interrogative pronouns, possessive pronouns, relative pronouns and indefinite pronouns. (Bussmann , 1996, p. 957)

Personal pronouns are a category of pronouns that denote persons. They can be classified into three categories: first- person pronouns which refer to the speaker and are represented by the pronouns "I and we", second - person pronouns which refer to the addressee and represented by the pronoun "you", and third - person pronouns which refer to other persons or things and are represented by pronouns like "he, she, it". (Trask, 2007, pp. 210 - 11; Bussmann, 1996, p. 883)

Personal pronouns go under the umbrella of deixes. They are called person deixes as they bear the main characteristics of deixes like indicating, pointing and referring (Yule,1996, pp. 9-10; Levinson ,1983, pp. 54, 62). Therefore, pronouns are mainly used to serve deictic functions (Chilton, 2004, p. 56). According to Mey (2001, pp. 56-7), understanding deictic expressions like pronouns 
and determining their referents depend on the context of their use whether this context is written or spoken .

Pronouns can be used in political discourse to serve different functions. These functions include "criticizing other people, insinuating, drawing attention to social or political problems, complaining about an antisocial act, and avoidance". Furthermore , pronouns can be used to reveal "friendliness or intimacy, social proximity or distance between the speaker and the referent". (Obeng \& Hartford, 2002, pp. 10 -11)

According to Chilton and Schaffner (1997, p. 216), "pronouns and the meanings associated with them give a kind of map of the socio-political relationships implicit in a discourse". Pronouns position the participants into certain political and social roles such as being an addresser who speaks, advices or orders or being an addressee who listens and receives the advice and the orders. Thus, the most important function of pronouns is to frame the relationships between all the participants: "addresser", "addressees", and "third-party 'overhearers"' and sometimes presupposed people who are not directly addressed by the speaker.

Personal pronouns like "I" achieve the political strategic functions of legitimization and coercion. It coerces the addressees to take the social and political roles imposed by the speaker, hence legitimizing the role of the speaker. It frames and positions the speaker as an "authoritative source of information or knowledge" and positions the audience as "subordinate, uninformed and unknowledgeable". Moreover, the use of the pronoun "I" with certain verbs of feeling or saying or actions or decisions such as (tell, say, criticize, condemn, take, order) represents the power of the speaker 
and positions him as "truthful narrator or messenger" and "man of action". (Chilton \& Schaffner , 1997, p. 217)

First person plural pronouns "we, us, our" can be used in political discourse to represent "group identity, coalitions, parties" and represent partners as insiders or outsiders. So they are used to serve not only linguistic functions but also political ones. (Chilton \& Schaffner, 2002 , p. 30)

The pronoun "we" and its variants "us", "our", "ours" serve important functions of positioning a politician in different relations with his party, his supporters, his government, or his nation. The pronoun "we" can be used to address different referents. It may refer to the speaker with some or all of the hearers (Chilton \& Schaffner, 1997, p. 218). Yule (1996) states that the pronoun "we" has two basic uses: inclusive and exclusive. Inclusive "we" means to include the addressee with the speaker. Exclusive "we" means the speaker includes some partners with him but excludes the addressee. (p. 11)

The pronouns "we, our, us" can be used strategically to legitimize the politician's position in different ways:

Strategic use of pronouns such as we, our, us in political discourse help political actors to act as spokespersons for the ordinary people. As Chilton notes, having been placed in the same camera angle as the ordinary people, the political actor legitimizes his opinion by seeming to anticipate the people's needs and desires. (Obeng \& Hartford, 2002, p. 11).

Obeng and Hartford (2002) state that politicians use the pronoun "we" and its variants "us" and "our" in political discourse to depict themselves as "spokespersons for the ordinary people". They follow Chilton as he confirms this 
same idea as he notices that politicians use these pronouns to represent the needs and hopes of their people and this in return helps to legitimize the politician's opinion. (p. 11)

Van Dijk (1998) as cited in Obeng \& Hartford (2002, p. 11) indicates that pronouns can be either inclusive or exclusive. Inclusive pronouns are "we and our" and exclusive pronouns are "you, your, their, and they". Politicians use such pronouns to express solidarity and allegiance or distance and prejudice. These pronouns also position politicians as an authoritative source of knowledge. In addition, on the text level, pronouns help in achieving unity and coherence between parts of the text through the different references made by the politician.

In political discourse, the pronoun "we" can be used strategically to achieve certain functions other than the aforementioned as indicated in Woods's (2014) words:

In the discourse of politics, the strategic use of the 'we' pronoun not only functions to create a [synthetic] personalized relationship between politicians and the public; it can also, by virtue of its implicit vagueness, serve to depersonalize or to obscure the agents of political actions. Sometimes the exact referents of 'we' are difficult to identify. If the speaker wants to avoid responsibility, he can use "we" instead of "I". (Woods ,2014, p. 74)

\section{Data of the Research}

The data of the current research consist of five transcripts of Barack Obama's international speeches to the Muslim and Non-Muslim foreign audiences during his rule from 2009 to 2015 .These speeches are addressed to the Muslim and Non- Muslim (Christians, Jews and Hindus) foreign audiences. They represent a variety of cultures, 
religions, themes, settings, audiences and political purposes. They were of national and international concern as they tackled critical issues that shape the relation between the USA and other countries and also they represent Barack Obama's perspective towards foreign policy. The transcripts of the speeches are downloaded from the official website of the White House and they are listed as seen in tables (1) and (2).

Table (1): International Speeches of Barack Obama to the Muslim World during his Rule from 2009 up to 2015

\begin{tabular}{|l|l|l|l|}
\hline No. & Title of the Speech & Date of Delivery & $\begin{array}{l}\text { Place of } \\
\text { Delivery }\end{array}$ \\
\hline 1 & $\begin{array}{l}\text { Remarks by the President } \\
\text { on a New Beginning at } \\
\text { Cairo University }\end{array}$ & June 4, 2009 & Egypt \\
\hline 2 & $\begin{array}{l}\text { Remarks by the President } \\
\text { at the University of } \\
\text { Indonesia in Jakarta. }\end{array}$ & $\begin{array}{l}\text { November10, } \\
2010\end{array}$ & Indonesia \\
\hline
\end{tabular}

Table (2): International Speeches of Barack Obama to the NonMuslim World during his Rule from 2009 up to 2015

\begin{tabular}{|l|l|l|l|}
\hline No & Title of the Speech & Date of Delivery & $\begin{array}{l}\text { Place of } \\
\text { Delivery }\end{array}$ \\
\hline 1 & $\begin{array}{l}\text { Remarks of President } \\
\text { Barack Obama To the } \\
\text { People of Israel }\end{array}$ & March 21, 2013 & Jerusalem \\
\hline 2 & $\begin{array}{l}\text { Remarks by President } \\
\text { Obama at the University } \\
\text { of Queensland }\end{array}$ & November 15, 2014 & Australia \\
\hline 3 & $\begin{array}{l}\text { Remarks by President } \\
\text { Obama in Address to } \\
\text { the People of India }\end{array}$ & January 27, 2015 & India \\
\hline
\end{tabular}




\section{Methodology of the Research:}

The current research employs the quantitative and qualitative methods of research. The quantitative method tackles frequencies and examples of analysis. The qualitative method, on the other hand, tackles the interpretation reached by the researcher . It adopts the theoretical frameworks of Chilton and Schaffner (1997) and Obeng and Hartford (2002) focusing on the analysis of first person pronouns "I" and "we". These approaches are selected as methods of research for their validity of investigating pronouns as persuasive tools. According to these approaches, the pronoun "I" is used to express feelings and emotions, narration, declarations, knowledge , personal views and thoughts. The pronoun "we" is used to express solidarity, allegiance, proximity and friendliness.

The researcher investigates and counts all the examples for each pronoun suggested along Barack Obama's international speeches under study. After counting the examples for each pronoun, the researcher gives frequency of occurrence for each one, interprets it and highlights the significance of their use. Indicative examples are provided from every speech for each pronoun chronologically and respectively. Examples are underlined and written in bold.

\section{Analysis and Discussion:}

For purposes of the present research, the researcher focuses on the analysis and investigation of first-person pronouns "I" and "we" . First - person pronouns subjected to analysis by the researcher according to Chilton and Schaffner's (1997) "have a special function in producing a social and political 'space' in which the speaker, the 
audience, and others are 'positioned"' (p.217). So they are selected for investigation because they depict the relation between Barack Obama and his addressees. Second- person pronoun "you" is excluded from analysis because it moves in one straight direction referring to the addressees all the time without political or rhetorical significance. Third person pronouns like "he , she , it, they" are excluded from investigation because they are considered "distal forms" (Yule ,1996 , p. 11) . They represent those who are not in direct interaction with the speaker and his addressees. Therefore, they can be prone to different interpretations so the researcher excludes them from her investigation. Occurrences of the pronouns "I" and "we" can be seen from the following tables:

Table (3): Frequency of all Occurrences of the Pronouns "I" and "we" in Barack Obama's International Speeches to the Muslim World during his Rule from 2009 to 2015 :

\begin{tabular}{|l|l|l|l|}
\hline \multirow{2}{*}{ No. } & \multirow{2}{*}{ Title of the Speech } & \multicolumn{2}{|l|}{ Pronouns Frequency } \\
\cline { 3 - 4 } & & I & we \\
\hline 1 & $\begin{array}{l}\text { Remarks by the President on a New } \\
\text { Beginning at Cairo University }\end{array}$ & 57 & 101 \\
\hline 2 & $\begin{array}{l}\text { Remarks by the President at the } \\
\text { University of Indonesia in Jakarta. }\end{array}$ & 53 & 47 \\
\hline
\end{tabular}


Table (4): Frequency of all Occurrences of the Pronouns "I" and "we" in Barack Obama's International Speeches to the NonMuslim World during his Rule from 2009 to 2015 :

\begin{tabular}{|l|l|l|l|}
\hline No & Title of the Speech & \multicolumn{2}{|c|}{ Pronouns Frequency } \\
\cline { 3 - 4 } & I & We \\
\hline 1 & $\begin{array}{l}\text { Remarks of President Barack Obama } \\
\text { To the People of Israel }\end{array}$ & 85 & 44 \\
\hline 2 & $\begin{array}{l}\text { Remarks by President Obama at the } \\
\text { University of Queensland }\end{array}$ & 74 & 132 \\
\hline 3 & $\begin{array}{l}\text { Remarks by President Obama in } \\
\text { Address to the People of India }\end{array}$ & 53 & 130 \\
\hline
\end{tabular}

\section{Analysis of the Pronoun "I":}

In light of Chilton and Schaffner (1997), the pronoun "I" is used in all the speeches to represent Barack Obama as an authoritative speaker who makes decisions, issues orders, commands, advices, informs, narrates, declares and describes. This establishes a positive self representation of Barack Obama, hence legitimizes his position as a leader and a man of action. It is used with influential verbs like: "believe, think, come, love, thank, participate, know, recognize, be, have, say, tell, do, answer, will, work, make, order, announce, promise, speak, ask, see, decide". All these verbs are recurrent in all of Barack Obama's international speeches to the Muslim and Non Muslim Worlds from 2009 to 2015. The conjunction of the pronoun "I" with these verbs proves Barack Obama's credibility and responsibility for what he says as well as achieves Obeng and Hartford (2002) friendliness, intimacy and social proximity. In addition, it 
positions Barack Obama as "truthful narrator or messenger", "authoritative source of information or knowledge" and "man of action" (Chilton \& Schaffner ,1997, p. 217).

\section{Feelings and Emotions:}

Barack Obama uses the pronoun "I" with certain adjectives, verbs and structures to describe his emotions and feelings so as to show friendliness, intimacy, social proximity and rapport. It is repeated five times in "Remarks by the President on a New Beginning, Cairo University", four times in "Remarks by the President at the University of Indonesia", six times in "Remarks of President Barack Obama To the People of Israel", six times in "Remarks by President Obama at the University of Queensland", and one time in "Remarks by President Obama in Address to the People of India". This can be seen from the following examples.

Ex (1):

Thank you very much. Good afternoon. I am honored to be in the timeless city of Cairo. . . . I'm grateful for your hospitality, and the hospitality of the people of Egypt. And I'm also proud to carry with me the goodwill of the American people, and a greeting of peace from Muslim communities in my country: Assalaamu alaykum. (Applause.) (Remarks by the President on a New Beginning, Cairo University, 2009). 
Ex (2):

... And I'm especially pleased that we have committed to double the number of American and Indonesian students studying in our respective countries. (Applause.) We want more Indonesian students in American schools, and we want more American students to come study in this country. (Applause.) . . . (Remarks by the President at the University of Indonesia in Jakarta, Indonesia, 2010).

Ex (3):

And as the President of a country that you can count on as your greatest friend -- (applause) -- $\underline{\mathbf{I}}$ am confident that you can help us find the promise in the days that lie ahead. And as a man who's been inspired in my own life by that timeless calling within the Jewish experience -tikkun olam -- (applause) -- I am hopeful that we can draw upon what's best in ourselves to meet the challenges that will come .... (Remarks of President Barack Obama To the People of Israel, 2013).

Ex (4):

On my last visit to this magnificent country three years ago, I had the privilege to meet some of the First Australians; we're joined by some today. So I want to begin by acknowledging the Traditional Owners of this land and by paying my respects to your elders, past and present. (Remarks by President Obama at the University of Queensland, 2014). 
Ex (5):

For all these reasons, India and the United States are not just natural partners. I believe America can be India's best partner. I believe that. (Applause.) Of course, only Indians can decide India's role in the world. But I'm here because I'm absolutely convinced that both our peoples will have more jobs and opportunity, and our nations will be more secure. . . (Remarks by President Obama in Address to the People of India, 2015).

In the abovementioned examples, Barack Obama expresses his emotions and feelings to the Muslim and Non-Muslim world respectively using emotional verbs and adjectives combined with the pronoun "I".

\section{Narration:}

Barack Obama uses the first-person pronoun "I" in narration about his life events so as to break the ice with his addressees and create a kind of familiarity and rapport with them. It is used four times in "Remarks by the President on a New Beginning, Cairo University", twenty times in "Remarks by the President at the University of Indonesia", three times in "Remarks of President Barack Obama To the People of Israel", twenty- nine times in "Remarks by President Obama at the University of Queensland", and fourteen times in "Remarks by President Obama in Address to the People of India" . This can be seen from the following examples: 
Ex (1):

Now part of this conviction is rooted in my own experience. I'm a Christian, but my father came from a Kenyan family that includes generations of Muslims. As a boy, I spent several years in Indonesia and heard the call of the azaan at the break of dawn and at the fall of dusk. As a young man, I worked in Chicago communities where many found dignity and peace in their Muslim faith. (Remarks by the President on a New Beginning, Cairo University, 2009).

Ex (2):

Let me begin with a simple statement: Indonesia bagian dari didi saya. (Applause.) I first came to this country when my mother married an Indonesian named Lolo Soetoro. And as a young boy I was -- as a young boy I was coming to a different world... . So we moved to Menteng Dalam, where -- (applause) -- hey, some folks from Menteng Dalam right here. (Applause.) And we lived in a small house. We had a mango tree out front. And I learned to love Indonesia while flying kites and running along the paddy fields and catching dragonflies, buying satay and baso from the street vendors. (Applause.) $\underline{I}$ still remember the call of the vendors. Satay! (Laughter.) I I remember that. Baso ! (Laughter.) But most of all, I remember the people -- the old men and women who welcomed us with smiles; the children 
who made a foreign child feel like a neighbor and a friend; and the teachers who helped me learn about this country. (Remarks by the President at the University of Indonesia in Jakarta, 2010).

Ex (3):

I'm going off script here for a second, but before I came here, I met with a group of young Palestinians from the age of 15 to 22. And talking to them, they weren't that different from my daughters. They weren't that different from your daughters or sons. I honestly believe that if any Israeli parent sat down with those kids, they'd say, I want these kids to succeed; I want them to prosper. (Applause.) I want them to have opportunities just like my kids do. I believe that's what Israeli parents would want for these kids if they had a chance to listen to them and talk to them. (Applause.) I believe that. (Remarks of President Barack Obama To the People of Israel, 2013).

Ex (4):

Part of the reason I have fond memories of Australia is I spent some time here as a boy when I was traveling between Hawaii and Indonesia, where_I lived for several years. And when_I returned three years ago as President, I had the same feelings that $I$ remembered as a child -- the warmth of the people of Australia, the sense of humor. I learned to speak a little "strine." (Laughter.) I'm tempted to "give it a burl." That's about as far as I can go actually. (Remarks by President Obama at the University of Queensland, 2014). 
Ex (5):

Our nations are strongest when we uphold the equality of all our people -- and that includes our women. (Applause.) Now, you may have noticed, I'm married to a very strong and talented woman. (Applause.) Michelle is not afraid to speak her mind, or tell me when $\underline{\mathbf{I} \text { 'm }}$ wrong -- which happens frequently. (Laughter.) And we have two beautiful daughters, so I'm surrounded by smart, strong women. And in raising our girls, we've tried to instill in them basic values -- a sense of compassion for others, and respect for themselves, and the confidence that they can go as far as their imaginations and abilities will carry them. And as part of Michelle's work as First Lady, she's met with women and girls around the world, including here in India, to let them know that America believes in them, too. (Remarks by President Obama in Address to the People of India, 2015).

These examples indicate that Barack Obama uses the pronoun "I" combined with verbs in the past tense to narrate actions and events about his life to the Muslim and Non- Muslim worlds successively. 


\section{Declaration:}

The pronoun "I" is used in conjunction with certain verbs of action and saying to declare certain actions. Barack Obama makes declarations and takes decisions which prove his authority and that he is a man of action. Declarations are used twenty- one times in "Remarks by the president on a new beginning, Cairo University", twenty-three times in "Remarks by the President at the University of Indonesia ", twenty- eight times in "Remarks of President Barack Obama To the People of Israel", twenty- five times in "Remarks by President Obama at the University of Queensland", and eighteen times in "Remarks by President Obama in Address to the People of India". This can be seen from the following examples:

Ex (1):

. . . I have unequivocally prohibited the use of torture by the United States, and_I have ordered the prison at Guantanamo Bay closed by early next year. (Applause.) (Remarks by the president on a new beginning, Cairo University, 2009).

Ex (2):

Innocent civilians in America, in Indonesia and across the world are still targeted by violent extremism. I made clear that America is not, and never will be, at war with Islam. . . . (Remarks by the President at the University of Indonesia in Jakarta, Indonesia, 2010). 
Ex (3):

But Iran must know this time is not unlimited. And I've made the position of the United States of America clear: Iran must not get a nuclear weapon. This is not a danger that can be contained, and as President, I've said all options are on the table for achieving our objectives. America will do what we must to prevent a nuclear-armed Iran. (Applause.) (Remarks of President Barack Obama To the People of Israel, 2013).

Ex (4):

Now, today, I'm announcing that the United States will take another important step. We are going to contribute $\$ 3$ billion to the Green Climate Fund so we can help developing nations deal with climate change. (Applause.) . . . (Remarks by President Obama at the University of Queensland, 2014).

Ex (5):

I realize that the sight of an American President as your chief guest on Republic Day would have once seemed unimaginable. But my visit reflects the possibilities of a new moment. As I've said many times, I believe that the relationship between India and the United States can be one of the defining partnerships of this century. When $\underline{\mathbf{I}}$ spoke to your Parliament on my last visit, I laid out my vision for how our two nations can build that partnership. And today, I want to speak 
directly to you -- the people of India -- about what I believe we can achieve together, and how we can do it. (Remarks by President Obama in Address to the People of India, 2015).

Along these examples, Barack Obama declares important actions using the pronoun "I" combined with different verbs like say, announce, order and speak. They prove his authority as a president and a man of action.

\section{Knowledge :}

Barack Obama employs the pronoun "I" with the verb "know" to express that he is a far-sighted man and has a good knowledge of everything. He proves Chilton and Schaffner's (1997) view that "the role of the politician is almost oracular. He is a guardian of the truth, a seer of the future, and a bringer of good tidings" (p.217) . In turn, this legitimizes the role and authority of Barack Obama. The verb "know" is used eleven times in "Remarks by the President on a New Beginning, Cairo University", twice in "Remarks by the President at the University of Indonesia", eleven times in "Remarks of President Barack Obama To the People of Israel", twice in "Remarks by President Obama at the University of Queensland", and one time in "Remarks by President Obama in Address to the People of India" . This can be seen from the following examples: 
Ex (1):

As a student of history, I also know civilization's debt to Islam. It was Islam -- at places like AlAzhar -- that carried the light of learning through so many centuries, paving the way for Europe's Renaissance and Enlightenment. ... . (Remarks by the President on a New Beginning, Cairo University, 2009).

Ex (2):

These are the issues that really matter in our daily lives. Development, after all, is not simply about growth rates and numbers on a balance sheet. . . . It's about whether those forces that have transformed the Jakarta I once knew -- technology and trade and the flow of people and goods -- can translate into a better life for all Indonesians, for all human beings, a life marked by dignity and opportunity. (Remarks by the President at the University of Indonesia in Jakarta, 2010).

$\operatorname{Ex}(3)$ :

And that brings me to the final area that I'll focus on: prosperity, and Israel's broader role in the world. I know that all the talk about security and peace can sometimes seem to dominate the headlines. . . . (Remarks of President Barack Obama To the People of Israel, 2013). 
Ex (4):

As we develop, as we focus on our econ, we cannot forget the need to lead on the global fight against climate change. Now, I know that's -(applause) -- I know there's been a healthy debate in this country about it. (Laughter.) Here in the Asia Pacific, nobody has more at stake when it comes to thinking about and then acting on climate change. (Remarks by President Obama at the University of Queensland, 2014).

Ex (5):

I know the argument made by some that it's unfair for countries like the United States to ask developing nations and emerging economies like India to reduce your dependence on the same fossil fuels that helped power our growth for more than a century. ... (Remarks by President Obama in Address to the People of India, 2015).

\section{Personal Views and Thoughts:}

Barack Obama uses the pronoun "I" with certain structures to express his personal views and his thoughts. It is used fourteen times in "Remarks by the President on a New Beginning, Cairo University", four times in "Remarks by the President at the University of Indonesia", thirty- five times in "Remarks of President Barack Obama to the People of Israel", eleven times in "Remarks by President Obama at the University of Queensland", and eighteen times in "Remarks by President Obama in Address to the People of India" . This can be seen from the following examples: 
Ex (1):

I am convinced that our daughters can contribute just as much to society as our sons. (Applause.) Our common prosperity will be advanced by allowing all humanity -- men and women -- to reach their full potential. I do not believe that women must make the same choices as men in order to be equal, and I respect those women who choose to live their lives in traditional roles. But it should be their choice.. . . (Remarks by the President on a New Beginning, Cairo University, 2009).

Ex (2):

I said then, and I will repeat now, that no single speech can eradicate years of mistrust. But $\underline{\mathbf{I}}$ believed then, and I believe today, that we do have a choice. We can choose to be defined by our differences, and give in to a future of suspicion and mistrust. Or we can choose to do the hard work of forging common ground . . . (Remarks by the President at the University of Indonesia in Jakarta, 2010).

Ex (3):

I also know, by the way, that not everyone in this hall will agree with what I have to say about peace. I recognize that there are those who are not simply skeptical about peace, but question its underlying premise, have a different vision for Israel's future. And that's part of a democracy. 
That's part of the discourse between our two countries. I recognize that. But I also believe it's important to be open and honest, especially with your friends. I also believe that. (Applause.) (Remarks of President Barack Obama To the People of Israel, 2013).

Ex (4):

... Bound by the values we share, guided by the vision we seek, I am absolutely confident we can advance the security and the prosperity and the dignity of people across this region. And in pursuit of that future, you will have no greater friend than the United States of America. (Remarks by President Obama at the University of Queensland, 2014).

Ex (5):

For all these reasons, India and the United States are not just natural partners. I believe America can be India's best partner. I believe that. (Applause.) Of course, only Indians can decide India's role in the world. But I'm here because I'm absolutely convinced that both our peoples will have more jobs and opportunity, and our nations will be more secure, and the world will be a safer and a more just place when our two democracies -- the world's largest democracy and the world's oldest democracy -- stand together. I believe that. (Applause.) (Remarks by President Obama in Address to the People of India, 2015).

Along these examples, Barack Obama employs the pronoun "I" with verbs like" recognize", "believe" and 
"convince" to express his thoughts and personal views. This proves his responsibility for these actions.

\section{Analysis of the Pronoun "We":}

Through analysis, it has been found that the personal pronoun "we" is highly recurrent in all of Barack Obama's international speeches from 2009 to 2015. It depicts the relationship between Barack Obama and his audiences. It is employed by Barack Obama to express solidarity, community, allegiance, proximity, and friendliness with his addressees as mentioned by Obeng and Hartford (2002). There are two forms of the pronoun "we" either inclusive or exclusive. The most recurrent form of the pronoun "we" is the inclusive form which includes the speaker with his addressees as one community. This helps to achieve rapport between Barack Obama and his addressees. On the other hand, exclusive "we" includes the speaker and some partners but excluding the addressees. This helps Barack Obama not only to represent himself, his country and his people but also legitimizes his position as a spokesperson for his nation. Analysis of the pronoun "we" in Barack Obama's speeches can be seen from the following examples and tables. 
Table (5): Frequency of all Occurrences of the Pronoun "we" in Barack Obama's International Speeches to the Muslim World during his Rule from 2009 to 2015 :

\begin{tabular}{|l|l|l|l|}
\hline \multirow{2}{*}{ No. } & Title of the Speech & \multicolumn{2}{|l|}{ Pronoun Frequency } \\
\cline { 3 - 4 } & $\begin{array}{l}\text { Inclusive } \\
\text { "we" }\end{array}$ & $\begin{array}{l}\text { Exclusive } \\
\text { "we" }\end{array}$ \\
\hline 1 & $\begin{array}{l}\text { Remarks by the President on a New } \\
\text { Beginning at Cairo University }\end{array}$ & 51 & 46 \\
\hline 2 & $\begin{array}{l}\text { Remarks by the President at the } \\
\text { University of Indonesia in Jakarta. }\end{array}$ & 19 & 27 \\
\hline
\end{tabular}

Table (6): Frequency of all Occurrences of the Pronoun "we" in Barack Obama's International Speeches to the Non- Muslim World during his Rule from 2009 to 2015:

\begin{tabular}{|l|l|l|l|}
\hline \multirow{2}{*}{ No } & Title of the Speech & \multicolumn{2}{|l|}{ Pronoun Frequency } \\
\cline { 3 - 4 } & $\begin{array}{l}\text { Inclusive } \\
\text { "we" }\end{array}$ & $\begin{array}{l}\text { Exclusive } \\
\text { "we" }\end{array}$ \\
\hline 1 & $\begin{array}{l}\text { Remarks of President Barack Obama } \\
\text { To the People of Israel }\end{array}$ & 22 & 18 \\
\hline 2 & $\begin{array}{l}\text { Remarks by President Obama at the } \\
\text { University of Queensland }\end{array}$ & 46 & 84 \\
\hline 3 & $\begin{array}{l}\text { Remarks by President Obama in } \\
\text { Address to the People of India }\end{array}$ & 86 & 43 \\
\hline
\end{tabular}

\section{Inclusive "we" :}

As the following examples indicate, the inclusive form of the pronoun "we" includes Barack Obama with his addressees as one community. This helps Barack Obama to 
establish rapport with his different foreign Muslim and Non-Muslim addressees and persuades them with his views:

Ex (1):

.... But I am convinced that in order to move forward, we must say openly to each other the things we hold in our hearts and that too often are said only behind closed doors. There must be a sustained effort to listen to each other; to learn from each other; to respect one another; and to seek common ground. As the Holy Koran tells us, "Be conscious of God and speak always the truth." (Applause.) That is what I will try to do today -- to speak the truth as best I can, humbled by the task before us, and firm in my belief that the interests we share as human beings are far more powerful than the forces that drive us apart. (Remarks by the President on a New Beginning, Cairo University, 2009)

Ex (2):

I said then, and I will repeat now, that no single speech can eradicate years of mistrust. But I believed then, and I believe today, that we do have a choice. We can choose to be defined by our differences, and give in to a future of suspicion and mistrust. Or we can choose to do the hard work of forging common ground, and commit ourselves to the steady pursuit of progress. And I can promise you -- no matter what setbacks may come, the United States is committed to human progress. That is who we are. That is what we've done. And that is what we will do. (Applause.) 
(Remarks by the President at the University of Indonesia in Jakarta, 2010)

Ex (3):

Together, we share a commitment to security for our citizens and the stability of the Middle East and North Africa. Together, we share a focus on advancing economic growth around the globe, and strengthening the middle class within our own countries. Together, we share a stake in the success of democracy. (Remarks of President Barack Obama To the People of Israel, 2013)

Ex (4):

And Australia really is everything that you would want in a friend and in an ally. We're cut from the same cloth -- immigrants from an old world who built a new nation. We're inspired by the same ideals of equality and opportunity -- the belief everybody deserves a fair go, a fair shot. And we share that same spirit -- that confidence and optimism -- that the future is ours to make; that we don't have to carry with us all the baggage from the past, that we can leave this world a better, safer, more just place for future generations. And that's what brings me here today -- the future that we can build together, here in the Asia Pacific region. (Remarks by President Obama at the University of Queensland, 2014) 
Ex (5):

Sisters and brothers of India, we are not perfect countries. And we've known tragedy and we've known triumph. We're home to glittering skyscrapers, but also terrible poverty; and new wealth, but also rising inequality. We have many challenges in front of us. But the reason I stand here today, and am so optimistic about our future together, is that, despite our imperfections, our two nations possess the keys to progress in the century ahead. We vote in free elections. We work and we build and we innovate. We lift up the least among us. We reach for heights previous generations could not even imagine. We respect human rights and human dignity, and it is recorded in our constitutions. And we keep striving to live up to those ideals put to paper all those years ago. (Remarks by President Obama in Address to the People of India, 2015)

\section{Exclusive "we":}

Barack Obama uses the pronoun "we" exclusively to represent himself and the American people excluding his present audiences. In so doing, he acts as spokesperson for his nation and he legitimizes his position as a leader. This can be seen from the following examples:

Ex (1):

But that same principle must apply to Muslim perceptions of America. (Applause.) Just as Muslims do not fit a crude stereotype, America is 
not the crude stereotype of a self-interested empire. The United States has been one of the greatest sources of progress that the world has ever known. We were born out of revolution against an empire. We were founded upon the ideal that all are created equal, and we have shed blood and struggled for centuries to give meaning to those words -- within our borders, and around the world. $\underline{\text { We }}$ are shaped by every culture, drawn from every end of the Earth, and dedicated to a simple concept: E pluribus unum -- "Out of many, one." (Remarks by the President on a New Beginning at Cairo University, 2009)

Ex (2):

. . . And I can promise you -- no matter what setbacks may come, the United States is committed to human progress. That is who we are. That is what we've done. And that is what we will do. (Applause.) (Remarks by the President at the University of Indonesia in Jakarta , 2010)

Ex (3):

But the source of our friendship extends beyond mere interests, just as it has transcended political parties and individual leaders. America is a nation of immigrants. America is strengthened by diversity. America is enriched by faith. We are governed not simply by men and women, but by laws. We're fueled by entrepreneurship and innovation, and we are defined by a democratic discourse that allows each generation to reimagine 
and renew our union once more. So in Israel, we see values that we share, even as we recognize what makes us different. That is an essential part of our bond. (Remarks of President Barack Obama To the People of Israel, 2013)

Ex (4):

The United States will continue to promote economic growth that is sustainable and shared. So we're going to work with APEC to tear down barriers to trade and investment and combat the corruption that steals from so many citizens. We'll keep opposing special preferences for stateowned companies. We'll oppose cyber-theft of trade secrets. We'll work with partners to invest in the region's infrastructure in a way that's open and transparent. We'll support reforms that help economies transition to models that boost domestic demand and invest in people and their education and their skills. (Remarks by President Obama at the University of Queensland, 2014)

Ex (5):

America wants to be your partner in igniting the next wave of Indian growth. As India pursues more trade and investment, we want to be first in line. We're ready to join you in building new infrastructure -- the roads and the airports, the ports, the bullet trains to propel India into the future. We're ready to help design "smart cities" that serve citizens better, and we want to develop more advanced technologies with India, as we do 
with our closest allies. (Remarks by President

Obama in Address to the People of India, 2015)

\section{Conclusion}

This research sought to analyze the persuasive pronouns in Barack Obama's international speeches to the Muslim and Non -Muslim worlds during his rule from 2009 to 2015. It analyzed six international speeches of Barack Obama. The researcher focused on the analysis of the pronouns "I" and "we". The results revealed that through the use of pronouns "I" and "we", Barack Obama not only establishes solidarity and rapport with his different foreign audiences but also persuades them of his thoughts and views. Also, it has been found that persuasive personal pronouns "I" and "we" are deliberately repeated in all the speeches to the Muslim and non-Muslim worlds. 


\section{References}

Allen, W. (2006) Australian political discourse: pronominal choice in campaign speeches. Selected papers from the 2006 conference of the Australian linguistic Society. Eds. M., Laughren \& I., Mushin. 2007

Al-Mizori, K. H. S. (2011). The linguistic methods USA Politicians used to justify the invasion of Iraq. Phd dissertation. ST Clements University. Mat. No. 15385

Aschale, A. (2013). A Critical discourse analysis of Barack Obama's speeches vis-à-vis Middle East and North Africa. $\mathrm{PhD}$ dissertation. Addis Ababa University, Addis Ababa. Retrieved from : https://www. files.ethz.ch/

Bussmann, H. (1996) Routledge dictionary of language and linguistics. Eds. \& Trans. G. P. Trauth\& and K. Kazzazi . London and New York: Routledge.

Chilton, P. (2004) Analyzing political discourse theory and practice. Routledge: London and New York.

Chilton, P \& Schaffner, C. (1997). Discourse and politics. discourse as social interaction. in T. A. Dijk (ed.), discourse studies: a multidisciplinary introduction._Vol 2. London: Sage . 206 - 230

Chilton, P. \& Schäffner, C. (2002). Themes and principles in the analysis of political discourse. In P. Chilton \& C. Schäffner(eds.) ,_Politics as text and talk: analytic approaches to political discourse. Amsterdam and Philadelphia :John Benjamins.

El-Hussari, I. A. (2010). President Bush's address to the nation on U.S. policy in Iraq: a critical discourse analysis approach. In U. Okulska \& P. Cap(eds.), Perspectives in Politics and Discourse. Amsterdam / Philadelphia: John Benjamins.

Fairclough, I. \& Fairclough, N . (2012). Political discourse analysis: A Method for Advanced Students. London and New York: Routledge. 
Fraser, B. (2010). Hedging in political discourse: The Bush 2007 Press Conferences. In U. Okulaska \& P. Cap (eds.), Perspectives in Politics and Discourse. The Netherlands: John Benjamins.

Gadalla, H. A. H. (2012). Ideological strategies in Barack Obama's Cairo speech: A critical discourse analysis. Published in Bulletin of the Faculty of Arts, Assiut University, Egypt. Vol. 41, pp. 9-45

Joseph, J. E. (2006). Language and politics. Great Britain: Edinburg University Press.

Levinson, S.C. (1983). Pragmatics. United Kingdom: The press syndicate of the University of Cambridge.

Mazlum, F. \& Afshin, S. (2016). Evaluative language in political speeches:

A

Case study of Iranian and American presidents' speeches. International Journal of Linguistics. 8 (4). doi:10.5296/ijl.v8i4.9398

Mey, L. J. (2001). Pragmatics an introduction ( $2^{\text {nd }}$ ed). United Kingdom: Blackwell .

Obeng, S. G. \& Harford , B. (2002). Surviving through obliqueness: language of politics in emerging democracies. New York: Nova Science .

Okulaska, U. \& Cap, P. (2010). Analysis of political discourse: Landmarks, challenges and prospects. In U. Okulaska and P. Cap, perspectives in politics and discourse. The Netherlands: John Benjamins.

Sajjad, F. (2015). A Critical discourse analysis of Barack Hussein Obama's political speeches on the Middle East and the Muslim world. International Journal of Linguistics . Vol. 7, No. 1.

Sharndama, E.C. \& Mgbemena, A. J. (2015). The Language of political discourse: A study of acceptance speeches of two presidential aspirants in Nigeria. Research Journal of English Language and Literature (RJELAL) . 
Trask, R.L. (2007). Language and linguistics the key concepts. Ed. Peter Stockwell ( $2^{\text {nd }}$ ed). London :Routledge.

Wales, K. (1996). Personal pronouns in present-day English. Great Britain : Cambridge University Press.

Woods, N. (2014). Describing discourse. A practical guide to discourse analysis. Great Britain and USA: Routledge.

Yule, G. (1996). Pragmatics. UK: Oxford University Press.

Yule, G. (2010). The study of language $\left(4^{\text {th }}\right.$ ed). Cambridge: Cambridge University Press.

Van Dijk, T .A. (2002). Political discourse and political cognition. In C., Schaffner \& P. A. Chilton (eds.) , politics as text and talk: analytic approaches to political discourse. Ed. John Benjaminns. 203 - 249

Van Dijk, T. A .(2004). Text and context of parliamentary debates. In P. Bayley (ed.), cross-cultural perspectives on parliamentary discourse . The Netherlands: John Benjamins. 339 - 369

\section{Online sources:}

Obama, B. (June 4 , 2009). " Remarks by the President on a New Beginning: Cairo University". Transcript. The White House. Last retrieved August 30, 2015. http://www.whitehouse.gov/the_press_office/Remarksby-the-President-at-Cairo-University-6-04-09/

. (November 10,2010). "Remarks by the President at the University of Indonesia in Jakarta, Indonesia" . Transcript. The White House. August 30, 2015.http://www.whitehouse.gov/the-pressoffice/2010/11/10/remarks- president- universityindonesia-jakarta-indonesia . (March 21,2013). Remarks of President Barack Obama To the People of Israel". Transcript. The White House. Last retrieved August 30, 2015. https://www.whitehouse.gov/the-press-office /2013/03/21/ remarks- president -barack-obama-people-israel 
----------. ( April 27, 2014). Remarks by President Obama at Young Southeast Asian Leaders Initiative Town Hall". Transcript. The White House. Last retrieved August 29, 2014 https: //www . whitehouse.gov/the-pressoffice/2014/04/27/ remarks -president -obama-youngsoutheast-asian-leaders -initiative-town-ha

- (November 15, 2014). "Remarks by President Obama at the University of Queensland". Transcript .The White House. Last retrieved August 28, 2015. https://www.whitehouse.gov/the-pressoffice/2014/11/15/remarks-president-obama-universityqueensland

. ( January 27, 2015). "Remarks by President Obama in Address to the People of India". Transcript. The White House . Last retrieved August 24 , 2015.https://www.whitehouse.gov/the-pressoffice/2015/01/27/ remarks-president-obama-address people -india 
114 